\title{
Herba houttuyniae extract induces apoptotic death of human promyelocytic leukemia cells via caspase activation accompanied by dissipation of mitochondrial membrane potential and cytochrome c release
}

\author{
Kang-Beom Kwon ${ }^{1}$, Eun-Kyung Kim ${ }^{1}$, \\ Byung-Cheul Shin ${ }^{2}$, Eun-A Seo ${ }^{3}$, \\ Jeong-Yeh Yang $^{4}$ and Do-Gon Ryu ${ }^{1,5}$ \\ ${ }^{1}$ Department of Physiology \\ ${ }^{2}$ Rehabilitation Medicine \\ School of Oriental Medicine \\ ${ }^{3}$ Medicinal Resources Research Center \\ Won-kwang University, Iksan 570-749, Korea \\ ${ }^{4}$ Institute of Oral Bioscience \\ Chonbuk National University, Chonju 561-756, Korea \\ ${ }^{5}$ Corresponding author: Tel, 82-63-850-6846; \\ Fax, 82-63-842-3138; E-mail, tkryu@wonkwang.ac.kr
}

Accepted 13 March 2003

Abbreviations: Ac-DEVD-AFC, N-acetyl-Asp-Glu-Val-Asp-AFC (7amino-4-trifluoromethyl-coumaine); Ac-DEVD-CHO, N-acetyl-AspGlu-Val-Asp-CHO (aldehyde); Ac-LEHD-AFC, N-acetyl-Leu-GluHis-Asp-AFC (7-amino-4-trifluoromethyl-coumaine); CsA, cyclosporin $\mathrm{A} ; \mathrm{DiOC}_{6}(3), 3,3^{\prime}$-dihexyloxacarbocyanine; HH, Herba houttuyniae; PARP, poly(ADP-ribose) polymerase

\begin{abstract}
Herba houttuyniae has been used as a constituent of herval medicine prescriptions for the treatment of inflammation, cancer, and other diseases. In the present study, we investigated the cellular effects of herba houttuyniae extract (HHE) and the signal pathways of HHE-induced apoptosis in HL-60 human promyelocytic leukemia cell line. HHE treatment caused apoptosis of cells as evidenced by discontinuous fragmentation of DNA, the loss of mitochondrial membrane potential, release of $\mathrm{mi}$ tochondrial cytochrome $c$ into the cytosol, activation of procaspase-9 and caspase-3, and proteolytic cleavage of poly(ADP-ribose) polymerase. Pretreatment of AC-DEVD-CHO, caspase-3 specific inhibitor, or cyclosporin A, a mitochondrial permeability transition inhibitor, completely abolished HHE-induced DNA fragmentation. Together, these results suggest that HHE possibly causes mitochondrial damage leading to cytochrome $c$ release
\end{abstract}

into cytosol and activation of caspases resulting in PARP cleavage and execution of apoptotic cell death in HL-60 cells.

Keywords: apoptosis; cancer; caspase; medicine, herbal; mitochondria; phytotherapy

\section{Introduction}

Herba houttuyniae, belongs to Houttuynia cordata $\mathrm{T}_{\text {HUNB }}$ (Saururaceae), is one of herbs that have been widely used in oriental medicine for treating allergy and cancer (Rho, 1998; Bae et al., 2000). Herba houttuyniae extracts (HHE) administered on the acupuncture point prevented the increase of mass weight of melanoma BBL16 tumor cells inoculated into mice (Bae et al., 2000). HHE treatment caused lowering of cell viability in various human cancer cell lines (Jung et al., 1996). But the mechanism of tumorcidal affect of Herba houttuyniae is not well understood.

Apoptosis is a specific process that leads to programmed cell death through the activation of an evolutionarily conserved intracellular pathway (Bold et al., 1997; Hall, 1999). Recently, many chemotherapeutic agents were reported to exert their anti-tumor effects by inducing apoptosis of cancer cells (Kamesaki, 1998). For example, PC-SPES, an eight-herb mixture, inhibited the proliferation of prostate cancer cells via apoptosis (Ikezoe et al., 2001) and has been used for prostate cancer therapy in USA (Marks et al., 2002). The molecular mechanisms of apoptosis have been extensively investigated in various models. Many investigators have demonstrated that mitochondria is a key regulator of apoptosis (Green and Reed, 1998; Susin et al., 1998). It seems that mitochondrial changes including transition of mitochondrial membrane potential, cytochrome $c$ release from mitochondria to cytosol provoke activation of series of caspases and finally cell death (Marchetti et al., 1996; Kroemer and Reed, 2000). Caspases involved in apoptosis are divided into two groups, the initiator caspases, which include caspase-2, -8, -9, and -10, and the effector caspases, which include caspase-3, -6 , and -7 (Shi, 2002). The activation of effector caspases by initiator caspases are responsible for the 
proteolytic cleavage of cellular substrates including actin, lamin, poly(ADP-ribose) polymerase (PARP) and inhibitors of deoxyribonuclease (such as DFF45 or ICAD) (Kaufmann et al., 1993; Shi, 2002). Cleavage of those substrates degrades the chromosomes into nucleosomal fragments during apoptosis (Enari et al., 1998; Liu et al., 1998).

In the present study, we investigated the molecular mechanism of HHE effects on HL-60 human promyelocytic leukemia cell line. HHE-induced apoptosis was accompanied by loss of mitochondrial membrane potential, release of cytochrome $c$ into cytosol, procaspase- 9 and caspase- 3 activation and PARP cleavage in HL-60 cells. Finally we confirmed discontinuous ladder pattern of DNA, one of apoptotic signs, by treatment with $\mathrm{HHE}$.

\section{Materials and Methods}

\section{Culture conditions}

The human leukemia cell line HL-60 was purchased from the American Type Culture Collection (Rockille, MD). Cells were placed into $75 \mathrm{~cm}^{2}$ tissue culture flasks and grown at $37^{\circ} \mathrm{C}$ under a humidified, $5 \% \mathrm{CO}_{2}$ atmosphere in RPMI 1640 medium (Life Technologies, Rockville, MD) supplemented with $10 \%$ FBS and $2 \mathrm{mM}$ glutamine, 10,000 units $/ \mathrm{ml}$ of penicillin, $10 \mathrm{mg} /$ $\mathrm{ml}$ of streptomycin, and $2.5 \mu \mathrm{g} / \mathrm{ml}$ of amphotericin $\mathrm{B}$.

\section{Preparation of herbal extract}

The plant was identified as Herba houttuyniae by Do-Gon Ryu, keeper of Herbarium. Voucher samples were preserved for reference in the Herbarium of Department of Physiology, School of Oriental Medicine, Wonkwang Univ. (Omcphy, 2001-22). For extraction, $200 \mathrm{~g}$ of Herba houttuyniae were added to $1800 \mathrm{ml}$ of water and boiled for $2 \mathrm{~h}$, filtered and then concentrated to $200 \mathrm{ml}$. The sterile extract $(58.55 \mathrm{~g})$ was stored at $-70^{\circ} \mathrm{C}$.

\section{MTT assay for cell viability}

The viability of cultured cells was determined by assaying for the reduction of MTT to formazan (Oez et al., 1990). In brief, after incubation with HHE, cells $\left(10^{4} /\right.$ well) in 96-well plates were washed twice with PBS and MTT $(100 \mu \mathrm{g} / 0.1 \mathrm{ml}$ of PBS) was added to each well. Cells were incubated at $37^{\circ} \mathrm{C}$ for $1 \mathrm{~h}$, and DMSO $(100 \mu \mathrm{l})$ was added to dissolve the formazan crystals. Absorbance was measured at $570 \mathrm{~nm}$ with a spectrophotometer (model E-MAX, Molecular Devices).

Measurement of mitochondrial membrane potential Mitochondrial membrane potential was determined as the retention of the dye 3,3'-dihexyloxacarbocyanine $\left(\mathrm{DiOC}_{6}(3)\right.$; Molecular Probes Inc, Eugene, OR). Cells $\left(5 \times 10^{5}\right.$ in $500 \mu$ l of complete RPMl 1640 medium) were loaded with $100 \mathrm{nM} \mathrm{DiOC}_{6}(3)$ during the last 30 min of treatment. The cells were then pelleted at 700 $g$ for $10 \mathrm{~min}$. The supernatant was removed, and the pellet was resuspended and washed twice in PBS. The pallet was then lysed by the addition of $600 \mu \mathrm{l}$ of deionized water followed by homogenization. The concentration of retained $\mathrm{DiOC}_{6}(3)$ was read on a spectrofluorometer (F-2500, Hitachi, Japan) with an excitation wavelength of $488 \mathrm{~nm}$ and an emission wavelength of $500 \mathrm{~nm}$.

\section{Detection of cytochrome c release}

The release of mitochondrial cytochrome $c$ was determined by Western blot (Kwon et al., 2001). Briefly, at the end of various designated treatments, cells (1.5 $\times 10^{7}$ cells) were washed with PBS, and resuspended in ice-cold homogenizing buffer $(250 \mathrm{mM}$ sucrose, $20 \mathrm{mM}$ Hepes- $\mathrm{KOH}(\mathrm{pH} 7.5), 10 \mathrm{mM} \mathrm{KCl}$, $1.5 \mathrm{mM} \mathrm{MgCl}$, $1 \mathrm{mM}$ EDTA, $1 \mathrm{mM}$ EGTA, $1 \mathrm{mM}$ DTT, $1 \mathrm{mM}$ PMSF, $1 \mu \mathrm{g} / \mathrm{ml}$ aprotinin, and $1 \mu \mathrm{g} / \mathrm{ml}$ leupeptin). After $30 \mathrm{~min}$ incubation on ice, cells were homogenized with a glass Dounce homogenizer (30 strokes). The homogenate was subject to a series of centrifugations at $100,000 \mathrm{~g}$ for $60 \mathrm{~min}$ for the collection of mitochondria pellets and cytosolic fraction. Mitochondria pellets were resuspended in lysis buffer and frozen at $-70^{\circ} \mathrm{C}$ for subsequent analysis. Thirty $\mu \mathrm{g}$ protein was loaded on $15 \%$ SDS polyacrylamide gel. After electrophoretic separation, the proteins were transferred to nitrocellulose membrane (Millipore, Bedford, MA) using a semi-dry blotting apparatus (BioRad, Munich, Germany), and the blot was incubated with mouse anti-cytochrome $c$ antibody (Pharmingen, San Diego, CA), followed by reaction with alkaline phosphatase conjugated secondary antibody.

\section{Caspase activity assay}

After treatment with $\mathrm{HHE}$, cells were washed with ice-cold PBS and lysed in Triton X-100 buffer $(0.5 \%$ Triton X-100, $10 \mathrm{mM}$ EDTA, and $10 \mathrm{mM}$ Tris- $\mathrm{HCl}, \mathrm{pH}$ 7.5) for $30 \mathrm{~min}$ on ice. Cell lysates were mixed with caspase assay buffer (10\% glycerol, $2 \mathrm{mM}$ DTT, and $20 \mathrm{mM}$ HEPES, pH 7.5) containing $20 \mu \mathrm{M}$ AcDEVD-AFC (specific for caspase-3) and $50 \mu \mathrm{M} \mathrm{Ac-}$ LEHD-AFC (specific for caspase-9), caspase substrates and incubated for $1 \mathrm{~h}$ at $37^{\circ} \mathrm{C}$. Enzyme catalyzed release of AFC was monitored using a spectrofluorometer (F-2500, Hitachi, Japan) with an excitation wavelength of $400 \mathrm{~nm}$ and an emission wavelength of $505 \mathrm{~nm}$. 


\section{Western blot analysis of procaspases and PARP cleavage}

Cell extract proteins were separated by SDS-PAGE. Subsequently the proteins were transferred onto a nitrocellulose membrane (Millipore) using a semi-dry blotting apparatus (Phamacia Biotech). Prior to incubation with antibodies against caspase-3, -9 and PARP (Transduction Lab.), membranes were blocked with $2 \%$ BSA for $30 \mathrm{~min}$. After washing the membranes, an alkaline-phosphatase coupled secondary antibody was added. The target proteins became visible following the addition of 5-bromo-4-chloro-3-indolyl phosphate/nitro blue tetrazolium (BCIP/NBT), a substrate of alkaline phosphatase.

\section{Detection of DNA fragmentation by gel electrophoresis}

Cell pellets $\left(3 \times 10^{6}\right)$ were resuspended in $500 \mu$ of lysis buffer $(0.5 \%$ Triton X-100, $10 \mathrm{mM}$ EDTA, and $10 \mathrm{mM}$ Tris- $\mathrm{HCl}, \mathrm{pH} \mathrm{8.0)}$ at room temperature for 15 min and centrifuged at $16,000 \times \mathrm{g}$ for $10 \mathrm{~min}$. DNA was then extracted twice with phenol/chloroform (1:1), precipitated with ethanol, and resuspended in Tris/ EDTA buffer $(10 \mathrm{mM}$ Tris- $\mathrm{HCl}, \mathrm{pH} 8.0$, and $1 \mathrm{mM}$ EDTA). DNA was analyzed after separation by gel electrophoresis ( $2 \%$ agarose).

\section{Protein determination}

The cytosolic protein concentration in HL-60 cells was determined by the method of Bradford (Bradford, 1976) with bovine serum albumin as the standard. All of the samples were assayed in triplicate.

\section{Statistical analysis}

Statistical analysis of the data was performed with Student's t-test and ANOVA. Differences with $P<$ 0.05 were considered statistically significant.

\section{Results}

MTT conversion assay was used to determine the viability of $\mathrm{HL}-60$ cells exposed to HHE. As shown in Figure $1 \mathrm{~A}$ and $1 \mathrm{~B}$, treatment with $\mathrm{HHE}$ decreased cell viability in a dose- and time-dependent fashion. The $I_{50}$ of $\mathrm{HHE}$ for cell viability was $0.5 \mathrm{mg} / \mathrm{ml}$.

To characterize the cell death of HL-60 cells, we further observed DNA fragmentation using agarose gel electrophoresis. DNA fragmentation was generally used as a marker of apoptotic cell death (Wyllie et al., 1980). DNA extracts from HL-60 cells treated with HHE $(1.0 \mathrm{mg} / \mathrm{ml})$ for $24 \mathrm{~h}$ displayed a characteristic ladder pattern of discontinuous DNA fragments (Figure 2, lane 2). Figure $3 \mathrm{~A}$ demonstrates HHE-induced loss of mitochondrial membrane potential (MMP). $\mathrm{HHE}$ reduced a retention time of $\mathrm{DiOC}_{6}(3)$ in a timerelated manner. Pretreatment of cyclosporin $A(C s A)$, a mitochondrial permeability transition inhibitor, for 30 min completely protected against MMP disruption by HHE (Figure 3B).

Since release of cytochrome $c$ from mitochondria into cytoplasm is considered to trigger a series of events leading to the activation of caspases, we determined whether HHE treatment could cause the translocation of mitochondrial cytochrome $c$ into cytoplasm. In untreated cells, most of cytochrome $c$ was localized in the mitochondria. However, the levels of
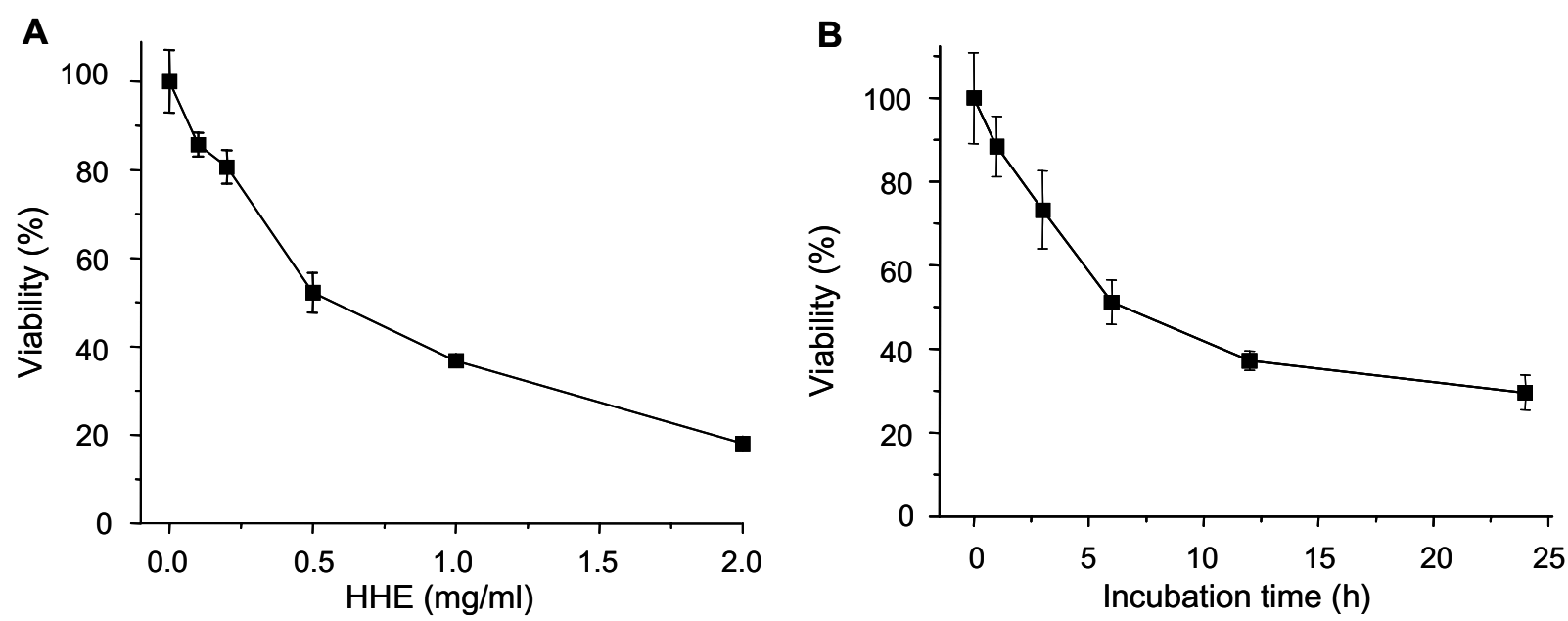

Figure 1. Effects of HHE on cell viability. (A) HL-60 cells $\left(1 \times 10^{5}\right)$ were treated with various concentrations of HHE for 24 h. (B) Cells were treated with $1.0 \mathrm{mg} / \mathrm{ml} \mathrm{HHE}$ for the indicated time periods. Their viability was determined by MTT assay. The percentage of viable cells was calculated as a ratio of $A_{570}$ of treated- to control cells (treated with $0.05 \%$ DMSO vehicle). Each value is the mean $\pm S E M$ of four independent experiments. 
cytosolic cytochrome $\mathrm{c}$ increased in a time dependent manner after HHE treatment (Figure 4A) and this translocation was inhibited by the pretreatment of CsA (Figure 4B).

To asses whether MMP alteration and cytochrome $c$ release are accompanied by activation of caspases that play a major role in execution of apoptotic events, the caspase enzyme activity was measured using specific fluorescence dyes, Ac-DEVD-AFC (specific for caspase-3) and Ac-LEHD-AFC (specific for caspase-

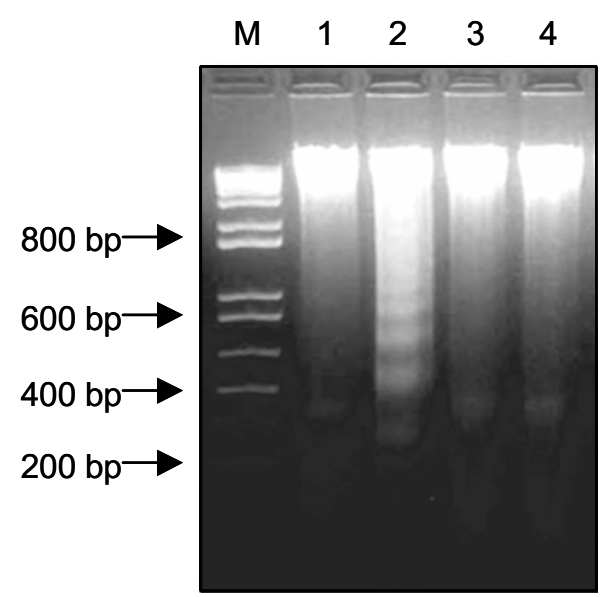

Figure 2. Inhibition of HHE-induced DNA fragmentation by CsA or caspase-3 inhibitor. HL-60 cells were treated with HHE for $24 \mathrm{~h}$ in the presence of CSA or Ac-DEVD-CHO. DNA was extracted and analyzed by $2 \%$ agarose gel electrophoresis as described in "Materials and Methods". Lane 1, control; Lane 2, $1.0 \mathrm{mg} / \mathrm{ml} \mathrm{HHE;} \mathrm{Lane} \mathrm{3,} 1.0$ $\mathrm{mg} / \mathrm{ml} \mathrm{HHE}$ with $5 \mu \mathrm{M} \mathrm{CsA}$, and Lane $4,1.0 \mathrm{mg} / \mathrm{ml}$ HHE with 25 $\mu \mathrm{M}$ Ac-DEVD-CHO.
9). As shown in Figure 5A, activation of caspase-3 occurred in a time-dependent manner. The cleavage of procaspase-9 in the cells treated with HHE was observed at $6 \mathrm{~h}$, prior to the cleavage of procaspase3 that started at $8 \mathrm{~h}$ (Figure $5 \mathrm{~B}$ and $\mathrm{C}$ ). PARP, a

\section{A} $\begin{array}{llllll}0 & 1 & 2 & 3 & 6 & (\mathrm{~h})\end{array}$
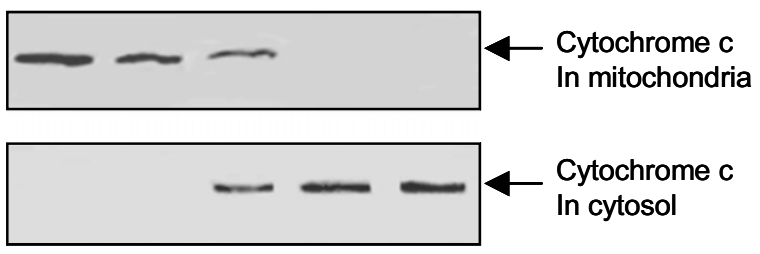

B

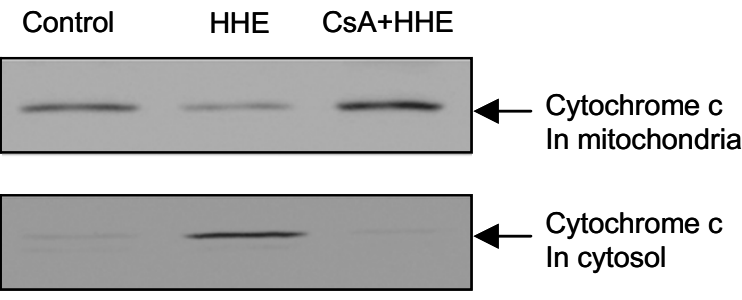

Figure 4. Effects of HHE on cytochrome $\mathrm{C}$ release from mitochondria to the cytosol. (A) HL-60 cells $\left(1.5 \times 10^{7}\right)$ were treated with $1.0 \mathrm{mg} / \mathrm{ml}$ HHE for the indicated time periods. (B) Cells were pretreated for 30 min with $5 \mu \mathrm{M} \mathrm{CsA}$ and then treated with HHE $(1.0 \mathrm{mg} / \mathrm{ml})$ for 6 h. Cytosolic and mitochondrial fractions were prepared and analyzed by western blotting as described in "Materials and Methods". Experiments were repeated three times with similar results and typical data were presented.
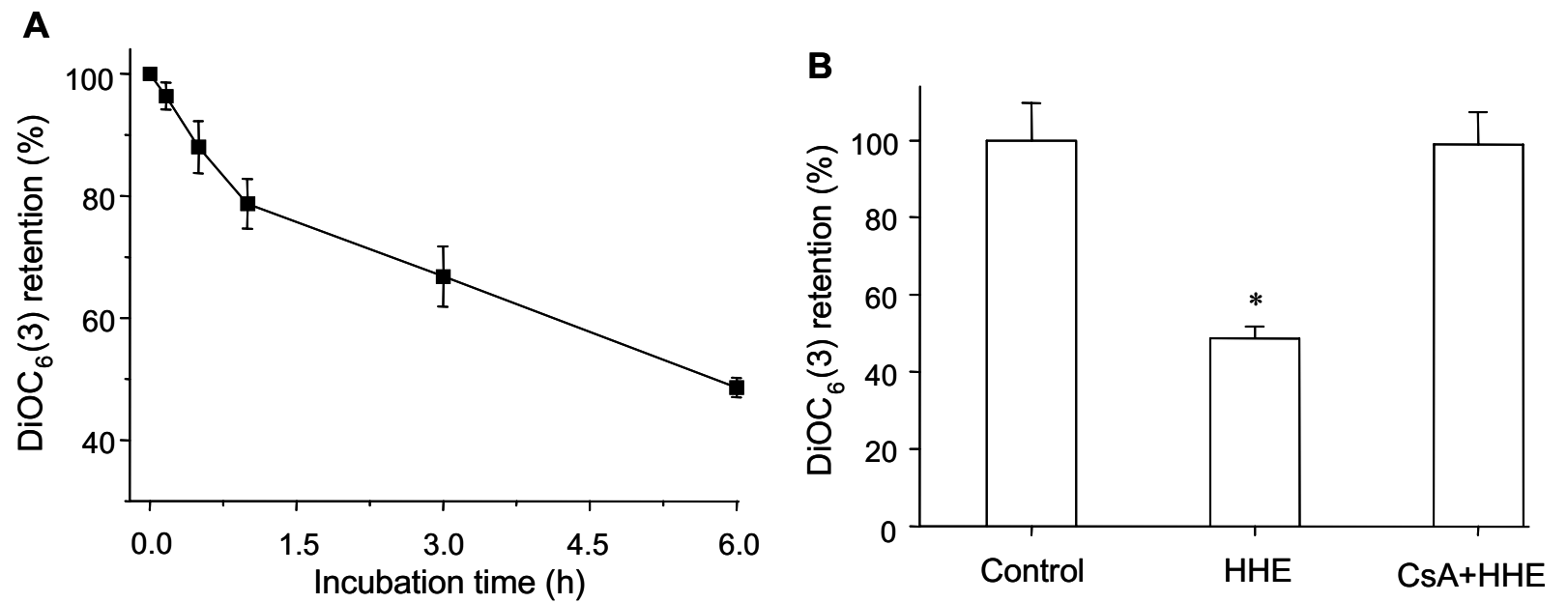

Figure 3. Effects of HHE on mitochondrial membrane potential in HL-60 cells. (A) Cells were treated with $1.0 \mathrm{mg} / \mathrm{ml}$ HHE for the indicated time periods. (B) Cells were pretreated for 30 min with $5 \mathrm{M} \mathrm{CsA}$ and then treated with HHE for $6 \mathrm{~h}$. During the last 30 min of treatment, $\mathrm{DiOC}_{6}(3)$ was added. An aliquot of the cells was used for the determination of cell-associated $\operatorname{DiOC}_{6}(3)$ fluorescence. Each value is the mean \pm SEM of six independent experiments. ${ }^{*} P<0.05$ compared with control. 

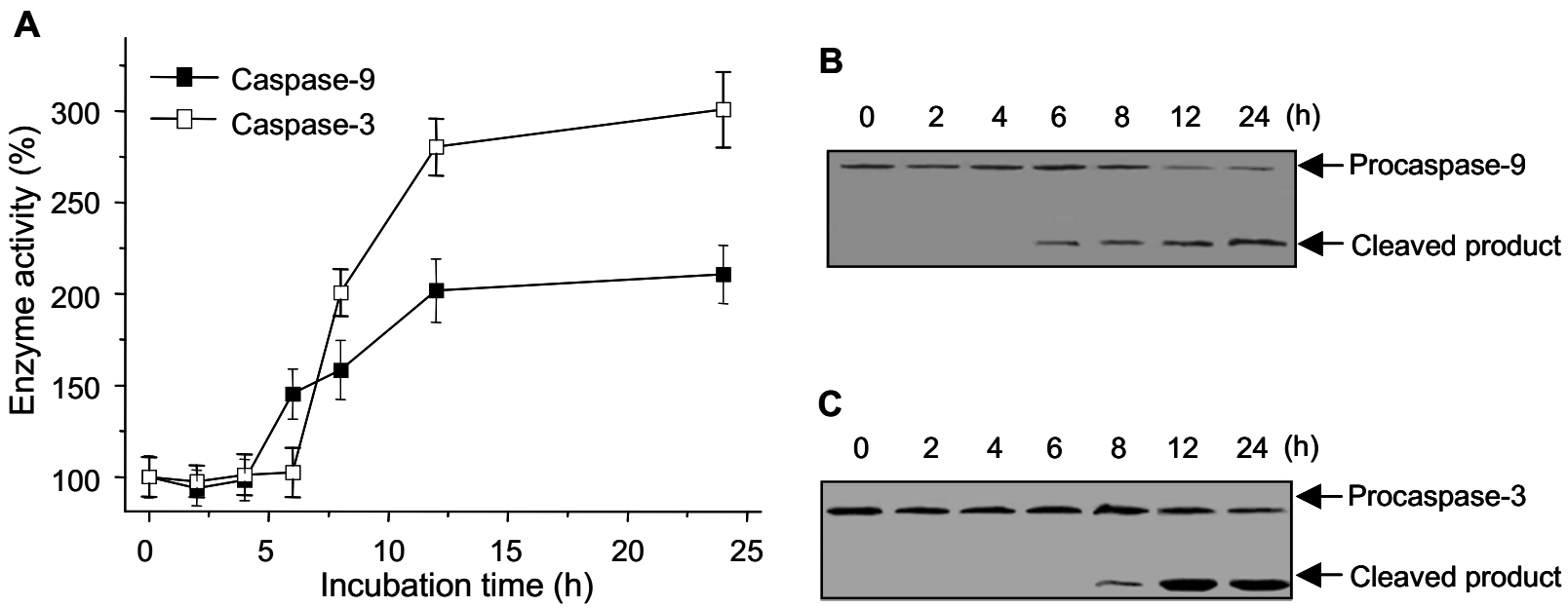

Figure 5. Induction of caspases activity and cleavage of procaspases by HHE. HL-60 cells $\left(5 \times 10^{\circ}\right)$ were treated with $1.0 \mathrm{mg} / \mathrm{ml} \mathrm{HHE}$ for the indicated time periods. Cytosolic extracts were assayed for caspase-3 and 9 activities (A) and used for Western blotting against procaspase-9 $(B)$, procaspase- $3(C)$ as described in "Materials and Methods". Values represent mean $\pm S E M$ of six separate experiments. Experiments were repeated three times with similar results and typical data were presented.

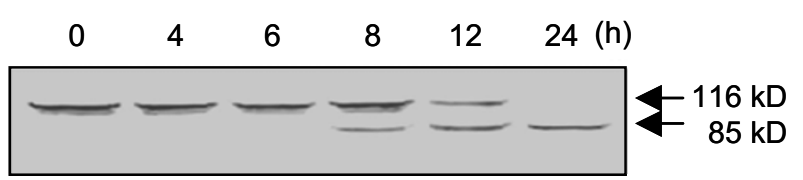

Figure 6. Time-related cleavage of PARP by HHE. HL-60 cells were treated with $1.0 \mathrm{mg} / \mathrm{ml} \mathrm{HHE}$ for the indicated time periods and the cleavage of PARP was analyzed by western blotting as described in "Materials and Methods". Experiments were repeated three times with similar results and a typical data was presented.

DNA repair enzyme, recognized as one of the downstream substrates of caspase- 3 and an excellent marker of apoptosis, was next examined as possible target substrates for HHE-treatment. Indeed HHEinduced activation of caspase- 3 caused PARP cleavage which separates $\mathrm{N}$-terminal DNA-binding domain from its C-terminal catalytic domain $(85 \mathrm{kDa})$ (Kaufmann et al., 1993). Figure 6 illustrated the gradual increase in the proportion of the $85 \mathrm{kDa}$ cleavage product in a time-dependent manner. These results correspond to activation and cleavage of caspase- 3 as shown in Figure $5 \mathrm{~A}$ and $\mathrm{C}$.

To further confirm the involvement of MMP disruption and of caspases in HHE-induced apoptosis of HL-60 cells, general inhibitors such as CsA and Ac-DEVD-CHO (specific inhibitor of caspase-3) were tested. When HL-60 cells were pretreated with $25 \mu \mathrm{M}$ Ac-DEVD-CHO or $5 \mu \mathrm{M} \mathrm{CsA}$, both caspase-3 activation and PARP cleavage by HHE treatment were completely blocked (Figure 7). Furthermore, the discontinuous ladder pattern of DNA induced by HHEtreatment was also prevented by the inhibitors (Figure
2, lane 3 and 4).

These observations suggest that MMP alteration, cytochrome $c$ release to cytosol, activation of caspase enzyme activity and PARP cleavage are involved in HHE-induced apoptosis of HL-60 cells.

\section{Discussion}

The present finding demonstrated that a herb medicine, HHE induces apoptosis of human promyelocytic leukemia cells through caspases activation involving dissipation of mitochondrial membrane potential and cytochrome $c$ release from mitochondria into the cytosol.

Cancer chemoprevention utilizing chemical compounds or natural products revert or inhibit malignant cell transformation and prevent invasion and metastasis would be a less painful, more economical and rational approach for cancer control. The use of natural herb medicines or dietary agents are being increasingly utilized as an effective way for the management of many cancer treatment (Mukhtar and Ahmad, 1999; Kelloff et al., 2000; Sporn and Suh, 2000; Setiawan et al., 2001). However their exact mechanisms involved in cancer prevention effects are not well understood.

Apoptosis is a biomarker in chemoprevention trials (Riss, 2001) and a complex process that involves many different signaling pathways and results in a multitude of changes in the dying cell. It is characterized by chromatin condensation, membrane blebbing, cell shrinkage, and DNA fragmentation (Wyllie et al., 1980). In this experiment, we found that cell death 


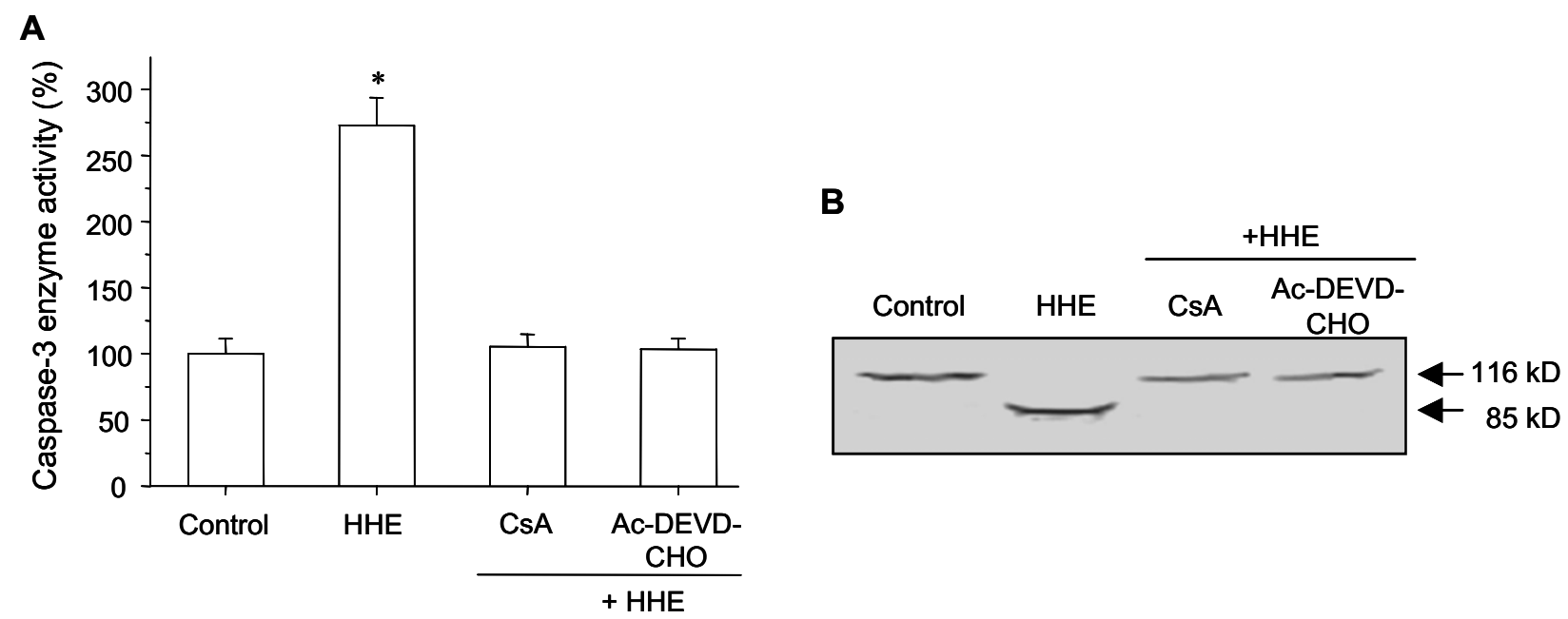

Figure 7. Inhibition of HHE-induced caspase-3 activation and PARP cleavage by CSA or AC-DEVD-CHO. HL-60 cells $\left(5 \times 10^{6}\right)$ were pretreated with Ac-DEVD-CHO $(25 \mu \mathrm{M})$ or CsA $(5 \mu \mathrm{M})$ for 30 min followed by treatment with $2.0 \mathrm{mg} / \mathrm{ml} \mathrm{HHE}$ for further $24 \mathrm{~h}$. Cytosolic extracts were prepared and assayed for caspase- 3 activity (A) and PARP cleavage (B) as described in Materials and Methods. Values represents means $\pm S E M$ of six separate experiments. ${ }^{*} P<0.05$ compared with control.

by HHE represents an apoptotic pattern as proved by DNA fragmentation in Figure 2. In the course of apoptosis, mitochondria have shown to be involved in integrating different pro-apoptotic pathways via release of cytochrome $c$ into the cytosol (Marchetti et al., 1996; Green and Reed, 1998). Also, it has been suggested that disruption of MMP plays a pivotal role in initiation of apoptotic induction and is related to the release of cytochrome $c$ (Marchetti et al., 1996; Li et al., 1997; Green and Reed, 1998). Once translocated into the cytosol, cytochrome $c$ interacts with Apaf-1, which permits recruitment of procaspase- 9 to form apoptosome, a critical activator of effector caspases including caspase-3 ( $\mathrm{Li}$ et al., 1997). In HL-60 cells, $\mathrm{HHE}$ produced a time-dependent loss of $\mathrm{DiOC}_{6}(3)$, a result demonstrating the specificity of CsA in preventing the loss of MMP. The fluorescent dye $\mathrm{DiOC}_{6}(3)$ localizes to mitochondria as a consequence of MMP, and the membrane permeability transition (MPT) reduces the accumulation of $\operatorname{DiOC}_{6}(3)$ as a consequence of the loss of MMP (Vayssiere et al., 1994; Krippner et al., 1996). The loss of MMP by $\mathrm{HHE}$ induced the redistribution of cytochrome $c$ from mitochondria into cytosol and the release of cytochrome $c$ into cytosol was inhibited by pretreatment of CsA in HHE-treated HL-60 cells. These results suggest that mitochondrial changes are participated in $\mathrm{HHE}$-induced death of HL-60 cells. The released cytochrome $c$ activated the pro-caspase 9 in a dATPdependent manner to form the apoptosome from which the release of activated caspase- 9 further initiates the activation of caspase cascade leading to biochemical and morphological changes associated with apoptosis (Li et al., 1997). Consistent with this report, $\mathrm{HHE}$ induced the activation and cleavage of procaspase- 9 from $6 \mathrm{~h}$ of HHE treatment, but activation and cleavage of procaspase- 3 was started from $8 \mathrm{~h}$ and sustained until $24 \mathrm{~h}$. Indicating that caspase- 9 is upstream of caspase 3 -like caspase, however there may be other mechanism(s) for caspase-3 activation apart from the cascade mediated through activation of caspase-9. Further studies are needed to investigate those additional pathways of caspase-3 activaton by $\mathrm{HHE}$. And involvement of other effector caspases $(-1,-6,-7)$ (Shi, 2002) in HHE-induced apoptosis of HL-60 cells cannot be excluded. The increase in caspase- 3 activity by HHE was accompanied by a PARP cleavage in a time-dependent fashion. Pretreating cells with the caspase-3 specific inhibitor, Ac-DEVD-CHO, and inhibitor of MMP dissipation, CsA, inhibited HHE-induced caspase-3 activation, PARP cleavage and DNA fragmentation. These results suggested the involvement of MMP damage, release of cytochrome $c$, activations of pro-caspase 9 and caspase-3, PARP cleavage in HHE-caused apoptotic death of HL-60 cells. However, in the present study, we did not notice any significant alterations in the level of Bcl-2 family of proteins localized at the outer mitochondrial membranes (data not shown). $\mathrm{Bcl}-2$ and related protein, $\mathrm{Bcl}-\mathrm{xL}$ exerts anti-apoptotic functions by preventing release of cytochrome $c$ from mitochondria into cytosol (Bossy-Wetzel and Green, 1999).

Consequently, the studies of these signaling pathways will advance our knowledge and understanding of the efficacy of many chemopreventive compounds some of which may become important therapeutic drugs of the future. 


\section{Acknowledgement}

This work was supported by grant No. (R05-2002000-00467-0) from the Basic Research Program of the Korea Science \& Engineering Foundation and partly Wonkwang University (2002).

\section{References}

Bae WY, Go HG, Kim CH. Experimental study on the effect of Houttuyniae Herbal Accupuncture on the growth of melanoma B16 in mice. J Korean Acupunture \& Moxibustion Society $2001 ; 18: 186-201$

Bold RJ, Termuhlen PM, McConkey DJ. Apoptosis, cancer and cancer therapy. Surg Oncol 1997;6:133-42

Bossy-Wetzel E, Green DR. Caspases induce cytochrome c release from mitochondria by activating cytosolic factors. J Biol Chem 1999;274:17484-90

Bradford MM. A rapid and sensitive method for the quantitation of microgram quantities of protein utilizing the principle of protein-dye binding. Anal Biochem 1976;72:248-54

Enari M, Sakahira H, Yokoyama H, Okawa K, Iwamatsu A, Nagata S. A caspase-activated DNase that degrades DNA during apoptosis, and its inhibitor ICAD. Nature 1998;391: 43-50

Green DR, Reed JC. Mitochondria and apoptosis. Science 1998;281:1309-12

Hall AG. Review: The role of glutathione in the regulation of apoptosis. Eur J Clin Invest 1999;29:238-45

Ikezoe T, Chen SS, Heber D, Taguchi H, Koeffler HP. Baicalin is a major component of PC-SPES which inhibits the proliferation of human cancer cells via apoptosis and cell cycle arrest. Prostate 2001;49:285-92

Jung HW, Choi JH, Jin CS. Effects of flos lonicerae and herba houttuyniae on human cancer cell-lines. Korean $\mathrm{J}$ Oriental Medical Pathology 1996;10:126-32

Kamesaki H. Mechanisms involved in chemotherapy-induced apoptosis and their implications in cancer chemotherapy. Int J Hematol 1998;68:29-43

Kaufmann SH, Desnoyers S, Ottaviano Y, Davidson NE, Poirier GG. Specific proteolytic cleavage of poly (ADP-ribose) polymerase: an early marker of chemotherapy-induced apoptosis. Cancer Res 1993;53:3976-85

Kelloff GJ, Crowell JA, Steele VE, Lubet RA, Malone WA, Boone CW, Kopelovich L, Hawk ET, Lieberman R, Lawrence JA, Ali I, Viner JL, Sigman CC. Progress in cancer chemoprevention: development of diet-derived chemopreventive agents. J Nutr 2000;130:467S-71S

Krippner A, Matsuno-Yagi A, Gottlieb RA, Babior BM. Loss of function of cytochrome $c$ in Jurkat cells undergoing fas- mediated apoptosis. J Biol Chem 1996;271:21629-36

Kroemer G, Reed JC. Mitochondrial control of cell death. Nat Med 2000;6:513-9

Kwon KB, Yang JY, Ryu DG, Rho HW, Kim JS, Park JW, Kim HR, Park BH. Vibrio vulnificus cytolysin induces superoxide anion-initiated apoptotic signaling pathway in human ECV304 cells. J Biol Chem 2001;276:47518-23

Li P, Nijhawan D, Budihardjo I, Srinivasula SM, Ahmad M, Alnemri ES, Wang $X$. Cytochrome $c$ and dATP-dependent formation of Apaf-1/caspase-9 complex initiates an apoptotic protease cascade. Cell 1997;91:479-89

Liu X, Li P, Widlak P, Zou H, Luo X, Garrard WT, Wang $X$. The $40-k D a$ subunit of DNA fragmentation factor induces DNA fragmentation and chromatin condensation during apoptosis. Proc Natl Acad Sci USA 1998;95:8461-6

Marchetti P, Castedo M, Susin SA, Zamzami N, Hirsch T, Macho A, Haeffner A, Hirsch F, Geuskens M, Kroemer G. Mitochondrial permeability transition is a central coordinating event of apoptosis. J Exp Med 1996;184:1155-60

Marks L, DiPaola R, Nelson P, Chen S, Heber D, Belldegrun A, Lowe F, Fan J, Leaders F, Pantuck A, Tyler V. PC-SPES: herbal formulation for prostate cancer. Urology 2002;60:369

Mukhtar $\mathrm{H}$, Ahmad N. Green tea in chemoprevention of cancer. Toxicol Sci 1999;52:111-7

Oez S, Platzer E, Welte K. A quantitative colorimetric method to evaluate the functional state of human polymorphonuclear leukocytes. Blut 1990;60:97-102

Rho BG. Studies on the antiallergic reactions of the herba houttuyniae. Korean J Herbol 1998;13:77-89

Riss TL. Apoptosis as a biomarker in chemoprevention trials. Urology 2001;57:141-2

Setiawan VW, Zhang ZF, Yu GP, Lu QY, Li YL, Lu ML, Wang MR, Guo CH, Yu SZ, Kurtz RC, Hsieh CC. Protective effect of green tea on the risks of chronic gastritis and stomach cancer. Int J Cancer 2001;92:600-4

Shi Y. Mechanisms of caspase activation and inhibition during apoptosis. Mol Cell 2002;9:459-70

Sporn MB, Suh N. Chemoprevention of cancer. Carcinogenesis 2000;21:525-30

Susin SA, Zamzami N, Kroemer G. Mitochondria as regulators of apoptosis: doubt no more. Biochim Biophys Acta 1998;1366:151-65

Vayssiere JL, Petit PX, Risler Y, Mignotte B. Commitment to apoptosis is associated with changes in mitochondrial biogenesis and activity in cell lines conditionally immortalized with simian virus 40. Proc Natl Acad Sci USA 1994;91: 11752-6

Wyllie AH, Kerr JF, Currie AR. Cell death: the significance of apoptosis. Int Rev Cytol 1980;68:251-306 